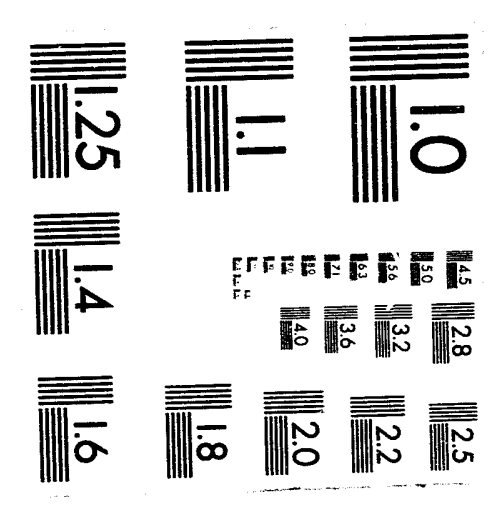



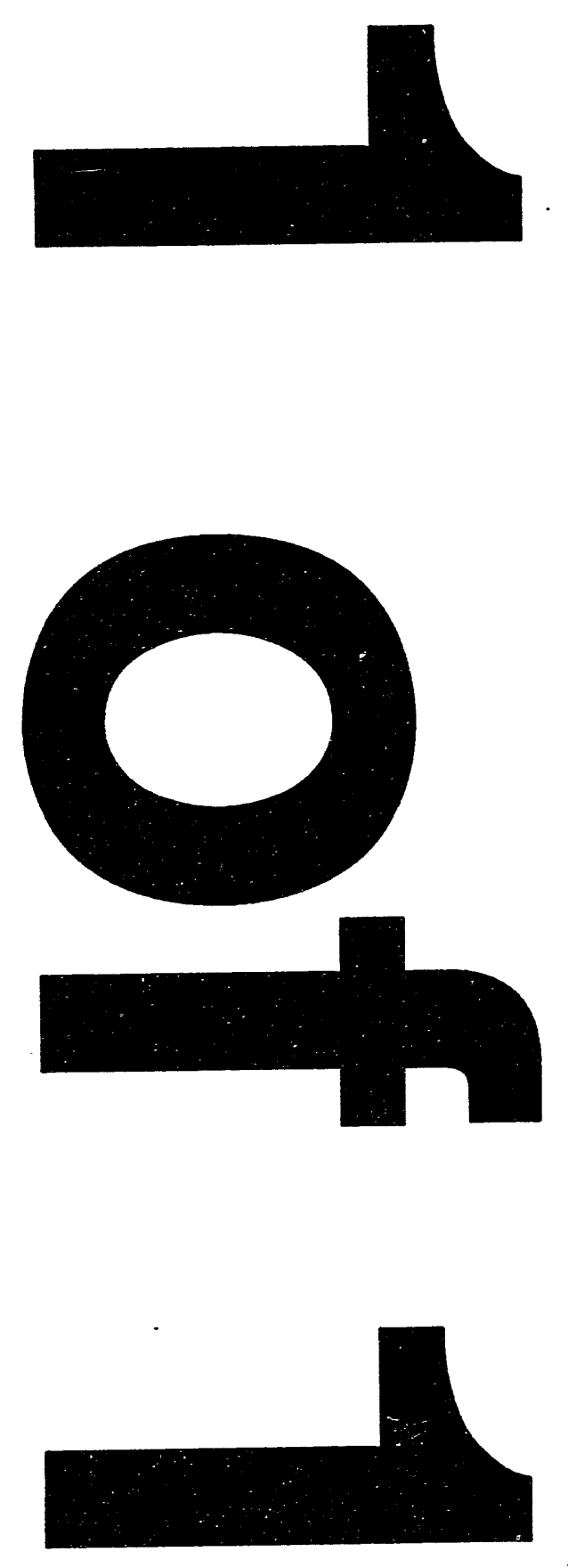
BNL- 49601

INFORMAL REPORT

\section{REGULATIONS, GUIDELINES, STANDARDS, AND POLICIES \\ PERTAINING TO DECONTAMINATION AND DECOMMISSIONING \\ ACTIVITIES: A LITERATURE REVIEW}

INFORMAL REPORT

M.G. Cowgill

SEPTEMBER 1993

Environmental and Waste Technology Center

Department of Advanced Technology

Brookhaven National Laboratory, Associated Universities, Inc.

Upton, New York 11973

United States Department of Energy

Contract No. DE-AC02-76CH00016

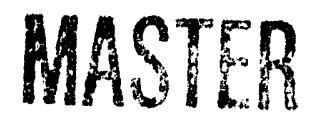




\begin{abstract}
A literature review has been conducted of the existing rules, regulations, and guidelines pertaining to the decontamination and decommissioning of nuclear facilities. Included in the survey are U.S. Government documents, national (industrial) standards, international standards and guidelines, and the regulations issued by various national governments, such as the United Kingdom, Canada, and Germany.
\end{abstract}


ABSTRACT $\ldots \ldots \ldots \ldots \ldots \ldots \ldots \ldots \ldots \ldots \ldots \ldots \ldots \ldots \ldots \ldots \ldots$ iii

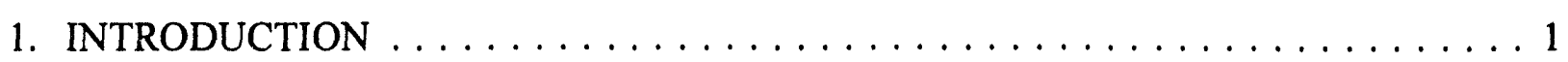

2. U.S. GOVERNMENT RULES, REGULATIONS, AND GUIDELINES $\ldots \ldots \ldots 3$

3. N`TIONAL (INDUSTRIAL) STANDARDS $\ldots \ldots \ldots \ldots \ldots \ldots \ldots$

4. INTERNATIONAL STANDARDS AND GUIDELINES $\ldots \ldots \ldots \ldots \ldots \ldots \ldots$

5. REGULATIONS IN THE UNITED KINGDOM $\ldots \ldots \ldots \ldots \ldots \ldots \ldots \ldots$

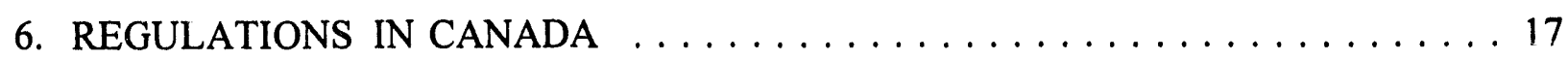

7. REGULATIONS IN GERMANY $\ldots \ldots \ldots \ldots \ldots \ldots \ldots \ldots \ldots \ldots \ldots \ldots$

8. REGULATION $\leqslant$ IN OTHER COUNTRIES $\ldots \ldots \ldots \ldots \ldots \ldots \ldots \ldots \ldots . \ldots \ldots$.

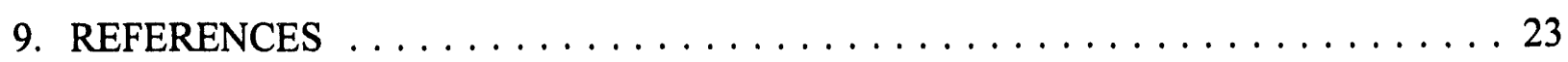




\section{INTRODUCTION}

The Department of Energy (DOE) complex contains within it a large number of nuclear facilities which will require decontamination and decommissioning (D\&D) in the coming years. This action will entail activities in many different areas, one of which will involve the development of the basic safety principles to be applied to the process as a whole. These principles will be used to guide personnel in the development of D\&D safety assessment procedures and in conducting safety assessments of D\&D activities at the facilities themselves.

Development of the principles will be based, in part, on information obtained during past D\&D operations at DOE and other facilities, both in the U.S.A. and in other countries. In the U.S.A., nuclear facilities are found in basically three sectors - the military, the civilian and the DOE. D\&D has taken place, and continues to take place, in all three but detailed information on the military sector operations is not readily available. Thus for the present task, attention was focused on the sets of guidelines that exist for D\&D of DOE facilities and those applicable to civilian operations. In addition, a survey has been made of the regulations and guidance issued by international organizations and by individual foreign countries. available.

It is the intent to update this report on a regular basis as additional information becomes . 


\section{U.S. GOVERNMENT RULES, REGULATIONS, AND GUIDELINES}

The U.S. Government has in place and under development many rules, regulations and guidelines which impact, directly or indirectly, on D\&D activities at nuclear facilities. The various Departments of the Federal Government have also issued standards to be used in the conduct of their business (e.g., MIL standards, for use in the development and manufacture of military components). These may be used during D\&D activities but, for the purpose of this review, are considered ancillary standards which do not determine the overall goal of the D\&D process or impact directly the operations which have to be performed.

The general rules and regulations developed by the various departments and agencies of the Federal Government appear first in the Federal Register (FR) and are later codified in the Code of Federal Regulations (CFR). The Code itself is divided into 50 titles which are representative of the broad areas subject to Federal regulation. Each title is divided into chapters bearing the name of the issuing agency, then subdivided into parts covering specific areas of regulation. The titles which have most direct relevance to D\&D activities are Title 10 (Energy), Title 29 (Labor), Title 40 (Protection of the Environment) and Title 49 (Transportation). Within Title 10, Parts 1 through 199 are the regulations issued by the Nuclear Regulatory Commission (NRC). The remaining Parts (200 to the end) of Title 10 are reserved to the rules and regulations of the DOE but it should be noted that very few of these Parts discuss the nuclear-centered activities which comprise a large portion of the agency's overall operations.

Examples of titles and their parts which should be consulted if D\&D of a nuclear facility is contemplated are:

10 CFR 20

10 CFR 30

10 CFR 40

10 CFR 50

10 CFR 51

10 CFR 70

10 CFR 71
(Standards for Protection Against Radiation)

(Rules of General Applicability to Domestic Licensing of Byproduct Material)

(Domestic Licensing of Source Material)

(Domestic Licensing of Production and Utilization Facilities)

(Environmental Protection Regulations for Domestic Licensing and Other Regulatory Functions)

(Domestic Licensing of Special Nuclear Material)

(Packaging of Radioactive Material for Transport and Transportation of Radioactive Materials Under Certain Conditions) 
10 CFR 72 (Licensing Requirements for Storage of Spent Fuel in an Independent Spent Fuel Storage Installation)

29 CFR 1910 (Occupational Safety and Health Administration)

40 CFR 190 (Environmental Radiation Protection Standards for Nuclear Power Operations)

40 CFR 191 (Environmental Radiation Protection Standards for Management and Disposal of Spent Nuclear Fuel, High Level Waste and Transuranic Waste)

40 CFR 192 (Health and Environmental Protection Standards for Uranium and Thorium Mill Tailings)

49 CFR $170 \quad$ (Hazardous Materials Regulations)

through

49 CFR 190

The above regulations are already in place but are under continued revision. In addition, there exist proposed rules which have yet to be acted upon; two examples of relevance to the current discussion are:

10 CFR 184 (Radiation Protection of the Public and the Environment)

40 CFR 194 (Radiation Protection Criteria for Cleanup of Land and Facilities Contaminated with Residual Radioactive Material)

These proposed rules, together with proposed changes to existing regulations have been published in the Federal Register (FR) and comments requested.

Individual departments in the Federal Government issue their own orders, guidance and clarification documents on specific subject areas arising from the general Federal rules and regulations appearing in the CFR.

The main DOE document DOE which addresses D\&D is DOE Order 5820.2A, issued September 26, 1988 [DOE 1988]. Chapter V deals solely with the decommissioning of radioactively contaminated facilities and lists the requirements associated with the implementation of decommissioning programs. These include the full characterization of the structures and materials involved, the conduct of environmental reviews, a description of the engineering planning for the project, the conduct of the decommissioning operations and the post decommissioning activities. DOE 5820.2A does not prescribe any quantitative limits related to such aspects as residual surface contamination and occupational exposure limits, the 
latter of which are to be found in DOE 5480.11 (Radiation Protection for Occupational Workers).

The DOE has also issued a Radiological Control (RadCon) Manual, DOE N 5480.6, [DOE 1992], the purpose of which is to present the DOE's radiological control program and establish the framework for implementation. In the event of conflict between a provision of the RadCon Manual and a provision of another DOE Order (e.g., DOE 5480.11), the RadCon Manual provision supersedes the other provision or specific exemption or waiver should be sought. Within the RadCon Manual itself, Chapter 3 makes specific reference to decommissioning work. This chapter, entitled Conduct of Radiological Work, covers aspects such as planning, work preparation, area entry and exit requirement, radiological work controls, and construction and restoration projects (including D\&D). Other chapters also contain information which would be applicable to D\&D work. Chapter 2, Radiological Standards, lists the various administrative control levels and dose limits, and surface contamination limits. Chapter 5, Radiological Health Support Operations, describes, among other items, how personnel will be monitored to enable compliance with the limits. On a different aspect of D\&D operations, Chapter 4, Radioactive Materials, includes description of the procedures associated with release of radioactive materials to controlled and uncontrolled areas (the criteria for release to the latter are described in DOE 5400.5).

In addition to the DOE, the Department's contractors often develop their own procedures and manuals. These manuals are not always available for public dissemination but information contained in them can sometimes be located in reports and papers. For example, Hine, in reporting on the D\&D of the SPERT-II and SPERT-III reactors [Hine 1981], reproduces the criteria used by EG\&G Idaho Inc. for the release of a facility for unrestricted use. The information itself was taken from EG\&G's safety manual for its radiation contamination control program [EG\&G 1978].

With reference to D\&D activities in the civilian sector, the NRC has issued several documents.

The Regulatory Guide 1.86, "Termination of Operating Licenses for Nuclear Reactors" [NRC 1974], was issued in June 1974 and continues in use to this day. It provides guidance on severil aspects associated with license termination, including what information to include when filing an application, what alternatives for retirement of a nuclear facility are acceptable to the NRC, the associated surveillance and security requirements, and reactor retirement procedures. There is also discussion of decontamination of a facility so that it may be released for unrestricted use and a table is provided of acceptable surface contamination levels. As discussed in [Wynveen 1985], these surface contamination limits were taken from a proposed draft of an American National Standards Institute (ANSI) standard, N328, which was never issued.

The NRC has also issued a Draft Regulatory Guide on the Standard Format and Content for Decommissioning Plans for Nuclear Reactors [NRC 1989] which has yet to be formalized. 
However, it provides a useful indication of the actions expected of a licensee when decommissioning a nuclear reactor. Decommissioning plans should include discussion of the decommissioning alternative selected, the activities involved, the facility radiological status (past and current), radiation protection, radioactive waste management, accident analyses and the final radiation survey plan.

Other NRC documents related to decommissioning rules and regulations include "Manual for Conducting Radiological Surveys in Support of License Termination" [Berger 1992] and "Residual Radioactive Contamination from Decommissioning" [Kennedy 1992]. Neither report provides numerical information concerning acceptable levels of activity and surface contamination but refers to extant criteria (such as Regulatory Guide 1.86).

The NRC is continually reappraising its regulatory position relative to the decommissioning of nuclear facilities. Such efforts have been in place since the late 1970s [Stello 1980] and a plan to reevaluate the NRC policy in this regard was issued in 1978 [NRC 1978]. Several studies were initiated at about the same time to develop information to support the preparation of new and/or revised decommissioning standards. The results included a series of reports on the technology, safety and costs of decommissioning various types of nuclear facilities (for example, nuclear reactors at multiple-reactor stations [Wittenbrock 1982]) and a comprehensive bibliography [Konzek 1978] (it should be noted that the DOE also produced a selected bibliography at about the same time - see [Faust 1980]). As part of the effort, Schilling et al. [Schilling 1979] produced a comprehensive review and analysis of the regulations current at that time. The authors looked at both those requirements (statutes, regulations, guidelines and standards) which specifically addressed decommissioning and those generic standards (for example, transportation) which might be applicable to decommissioning activities. Conti [Conti 1980] has described some results obtained during the development of residual radioactivity criteria.

The information collected in the reevaluation program were used extensively in the production of a generic environmental impact statement concerning decommissioning of nuclear facilities [NRC 1988]. This comprehensive document discusses generic nuclear facility decommissioning considerations, including decommissioning alternatives, residual radioactivity levels for unrestricted use, financial requirements and waste management issues. The report addresses in detail the decommissioning of more than a dozen types of nuclear facilities, in each case comparing the decommissioning alternatives available based on radiation safety, costs and environmental consequences. The final section of the report reviews the policy considerations before the NRC and major regulatory aspects, and makes recommendations concerning essential regulatory actions.

Incentive, if needed, to continue the reevaluation program came with the issuing of a report by the U.S. General Accounting Office (GAO) [GAO 1989]. In addition to pointing out instances of apparently poor regulatory oversight, the GAO highlighted the fact that "no federal standards exist for acceptable levels of radiation that can remain after the NRC terminates a 
license. As a result, licensees are using NRC guidance developed in the early 1970s to decommission their facilities."

At the present time, the NRC is pursuing a more consultative approach to rulemaking [Cameron 1992; Kovach 1992] and has recently completed a series of workshops, the results of which will be used in developing a proposed rule on radiological criteria for the decommissioning of NRC-licensed facilities. The workshop discussions, announced in the Federal Register (57 FR 58727, December 11, 1992), used as a focal point a Rulemaking Issues Paper which treats both the objectives for developing radiological criteria and the application of practicality considerations. The outcome of the workshops and the proposed rules have yet to be published.

As with the NRC, the Environmental Protection Agency (EPA) is in the process of developing and establishing standards applicable to D\&D activities. Crofford [Crofford 1980] provides an early overview of the EPA's plan in this area. Among the items he discusses, in general terms, are the need to review existing standards, regulations and criteria, the costs associated with decommissioning, the need for financial provisions, and occupational radiation protection. Lichtman and Ronca-Battista, in [Lichtman 1985], provide a later discussion of developments at the EPA concerning residual radioactivity criteria. The authors describe efforts on a pathway analysis which relates residual radioactivity levels to doses to such as onsite individuals and also the compilation of an inventory of site and facility characteristics (more details on the latter can be found in [Ronca-Battista 1985]).

[Voilleque 1985] reviewed the radiation protection guidance in existence in 1985 and that anticipated, covering the activities and actions of the International Commission on Radiological Protection (ICRP), the National Council on Radiation Protection and Measurements (NCRP), the EPA, the NRC, the DOE and other groups. The ICRP and NCRP provide recommendations and guidance on radiation protection, the adoption of which is left up to the individual national and international legislative bodies. Voilleque describes how these recommendations are derived and what their values are. There is also discussion of the "de minimis" concept, the definition of which the author places much emphasis because of possible misconceptions about what it represents. Considerably more in-depth discussion of the "de minimis" radiation dose, including a tabulation of dose recommendations of numerous national and international agencies, can be found in [Kocher 1985]. "De minimis" dose limitation is similar to, but not quite the same as, the "below regulatory concern" policy proposed by the NRC in 55 FR 27522, July 3, 1990, but later withdrawn.

[Cantor 1986] provides an analysis of the regulatory environments surrounding decommissioning of commercial nuclear power plants. The purpose of the study was to identify some of the trends in regulations and regulatory practices that would significantly affect the costs, technical alternatives and financing schemes associated with such projects. There is some discussion of the technical aspects and the factors which influence the selection of the method of decommissioning, including residual radioactivity levels and occupational 
exposure doses. However, the report is mostly concerned with analyzing the costs and funding needs associated with the various scenarios and technical alternatives. 


\section{NATIONAL (INDUSTRIAL) STANDARDS}

Standards applicable to the decommissioning of nuclear facilities have been developed, or are in the process of development, by various professional societies. These include the American Society for Testing and Materials (ASTM), the American Nuclear Society (ANS), the American Society of Mechanical Engineers (ASME) and the Health Physics Society (HPS). Some of the activities of these societies are described in [Steffes, 1988].

The ASTM has issued several standards which are relevant to D\&D operations. These include:

E 1281 (Nuclear Facility Decommissioning Plans) [ASTM 1989]

E 1278 (Radioactive Pathway Methodology for Release of Sites Following Decommissioning) [ASTM 1988]

E 1167 (Radiation Protection Program for Decommissioning Operations) [ASTM 1987a]

E 1168 (Guide for Radiological Protection Training for Nuclear Facility Workers) [ASTM 1987b]

E 1034 (Nuclear Facility Transient Worker Records) [ASTM 1985]

The scope of ASTM E 1281 applies to the decommissioning plans for any nuclear facility, including those whose operation is governed by NRC or Agreement State license or is under DOE orders. It identifies the elements which should be included in a decommissioning plan, provides a list of activities which might typically be associated with decommissioning a facility and indicates some of the documentation which might be necessary to support a decommissioning program.

The stated purpose of ASTM E 1278 is "to provide guidance in determining site-specific conversion factors for translating between dose limits and residual radioactive contamination levels on equipment, structures and land areas." It does not endorse specific levels of allowable residual contamination and points out that such standards are not yet available for all types of nuclear facilities. An extensive section of the guide is devoted to pathway analysis and covers pathway analysis objectives, site-specific pathway analyses, and the basis and methods of calculating pathway doses, including a diagram showing potential pathways that could result in off-site doses.

ASTM E 1167 defines and discusses elements that should be addressed in a radiation protection plan for a decommissioning project. These include radiation safety organization and responsibilities, radiological control areas, sources and types of radiation, radiological survey plans, ALARA programs, external and internal radiation exposure control, and decontamination. Although the guide discusses radiological release criteria, it does not provide any specific details, stating only that they "should be based upon applicable limits for unrestricted release." The Appendix to the guide provides an extensive list of general references and related standards. 
ASTM E 1168 is directed toward the provision of appropriate training for workers in radiologically controlled areas in nuclear facilities. Such training programs are particularly pertinent for operational facilities but they are also of relevance when a facility is being decommissioned. The guide provides detailed guidance on how to administrate such a program and addresses the many topics which should be included in the training program.

D\&D activities will probably involve workers being employed temporarily at several sites over time and this brings about a concern regarding adequate monitoring of the cumulative radiation doses of individual workers. ASTM E 1034 describes the required content of records needed for processing such personnel. These include information on the occupational radiation exposure for the current quarter and the lifetime history, and data on the worker's security clearance and radiation training record.

The ANS has issued one standard which directly addresses decommissioning. Approved by the American National Standards Institute, this is ANSI/ANS-15.10-1981, "Decommissioning of Research Reactors" [ANSI 1981]. The document includes discussion of such aspects as decommissioning alternatives, planning, surveillance, environmental assessment, quality assurance, and reporting and documentation. It recommends that plans for decommissioning should be included in the design stage for new facilities and, for existing operating reactors, in the design of major facility modifications. Items to be considered include occupational exposure, decontamination, work procedures, maintenance and surveillance andfinancial planning. On the subject of unrestricted use criteria, acceptable surface contamination levels are identical with those given in Regulatory Guide 1.86. The document points out that no unrestricted use criteria have been established for neutron-activated materials and that these are to be determined on a case basis by the cognizant regulatory authority.

The HPS Standards Committee was instrumental in developing the first surface contamination limits for materials and facilities to be released for unrestricted use [Wynveen 1985]. A proposed draft of ANSI N328 was completed in 1974 but never formally issued. Subsequently, the HPS Conmittee adapted N328 into several drafts and proposals of ANSI N13.12. As mentioned above, the limits contained in the proposed draft of ANSI N328 found their way into the NRC Regulatory Guide 1.86. Tabulations of the surface contamination limits proposed at various times can be found in [Wynveen 1985]. 


\section{INTERNATIONAL STANDARDS AND GUIDELINES}

The central international body for atomic energy-related matters, the International Atomic Energy Agency (IAEA), has issued many documents related to the D\&D of nuclear facilities. Most of the publications serve to provide overviews of the various aspects and activities associated with $D \& D$, based on the ideas, experiences and developments in the Member States and in other international organizations. Some, of more interest in the context of the present report, present draft codes and guidelines which can serve as bases for the development of rules and regulations by individual nations and groups of nations. It should be emphasized, however, the authority to impose such rules and regulations concerning D\&D operations in a particular State rests ultimately with the Government in that State. The rules and regulations implemented by various national governments are treated in later separate sections of the present report.

An overview of the IAEA's work in the development of standards and regulations, and other aspects, of decommissioning can be found in [Feraday 1985] and [De 1991]. Also, the Nuclear Energy Agency of the Organization for Economic Cooperation and Development (NEA/OECD) has in place a cooperative program on decommissioning of nuclear installations, one of whose objectives is to promote cooperation between its member countries on the safety and regulatory aspects of nuclear development, including decommissioning [Bertini 1986; Jones, 1993].

The basic general publication with regards to D\&D is Safety Series (SS) No. 52, Factors Relevant to the Decommissioning of Land-Based Nuclear Reactor Plants [IAEA 1980]. This document contains information on procedures, techniques and criteria covering all aspects of the process and is intended to provide assistance to those planning or implementing a decommissioning action. Topics addressed include the basic stages of decommissioning, decommissioning plans, the radiation protection program, and the criteria for the release of materials, facility or site. With respect to the last-named, the publication offers no quantitative guidance, deferring such matters to the "appropriate regulatory bodies."

Another publication in the Safety Series, No. 105, is titled "The Regulatory Process for the Decommissioning of Nuclear Facilities" [IAEA 1990]. The objective in this case is to provide general guidance for the regulation of decommissioning of nuclear facilities within established regulatory frameworks. It states that decommissioning regulations should "provide for the safety and radiological protection of the public and workers" and "reduce environmental impacts to acceptable levels." It requires that the recommendations of the ICRP [ICRP 1977] and the IAEA [IAEA 1982] concerning the basic principles of radiation protection be adopted during decommissioning. It also points out that large amounts of waste, both radioactive and nonradioactive, will probably be created and consideration should be given to methods of controlling this and later disposing of it. The publication devotes separate sections to such items as planning for decommissioning, its facilitation, cost estimates and funding sources, and the responsibilities and functions of the various parties involved. 
SS No. 74, "Safety in Decommissioning of Research Reactors," [IAEA 1986a] supplements the Code of Practice on the Safe Operation of Research Reactors and Critical Assemblies (Safety Series No. 35) and provides guidance on how to meet the safety requirements on decommissioning contained therein. Among the items covered are the sequencing of decommissioning activities, the contents of the decommissioning plan, the safety evaluation and the actual decommissioning process. The last of these includes subsections on fuel removal, decontamination, dismantling, radiation protection and waste management. The publication notes that the requirements of any national radiation protection and waste management regulations must be met or, if such have not been formulated, international recommendations may be followed.

Decommissioning of mines, mills and associated waste management facilities is addressed in SS No. 85, "Safe Management of Wastes from the Mining and Milling of Uranium and Thorium Ores: Code of Practice and Guide to the Code" [IAEA 1987a]. The Code of Practice contained in this publication is regarded as mandatory for the IAEA's own operations and for operations to which the Agency provides assistance. Guidance relevant to specific decommissioning requirements is found in Section 11 of the Code, including information on the status in several Member States (U.S.A., Canada, Australia and France).

In addition to the "Safety Series" publications, the IAEA publishes information in a "Technical Reports Series" (TRS). As the title implies, this series of documents is directed" more towards the technical aspects of nuciear-related problems. For example, in the case of decommissioning, information is provided more in the form of how to accomplish the actual act, rather than what activities need to be considered and what criteria should be met. Nevertheless, the documents often contain mention and reference to the latter requirements.

TRS No. 267, "Methodology and Technology of Decommissioning Nuclear Facilities," [IAEA 1986b] discusses briefly the basic stages of decommissioning and the considerations which affect the selection of a decommissioning process for a particular nuclear facility in the initial part of the document. Later, the document addresses the need for national policies in decommissioning and reviews some of the criteria for release of equipment, materials and sites. It points out that, at that time (1986), no country had established regulatory limits which would allow unrestricted release of very low level radioactive waste. The release of such material is generally handled on a case by case basis, using ad hoc release criteria, the ranges of some values of which are given in the report.

TRS No. 278, "Methods for Reducing Occupational Exposures During the Decommissioning of Nuclear Facilities," [IAEA 1987b] provides little information on standards and regulations. It reiterates the three fundamental principles of the system of dose limitation proposed by the ICRP [ICRP 1977] and the IAEA [IAEA 1982], and discusses the technical and economic factors which need to be considered. However, the bulk of the document is given over to describing, as might be expected from the title, methods for reducing occupational exposures. 
Similar comments apply to TRS No. 230, "Decommissioning of Nuclear Facilities: Decontamination, Dismantling and Waste Management" [IAEA 1983]. The first few pages describe in general terms considerations important to decommissioning but the subsequent sections address the methods by which decontamination, dismantling and waste management may be performed. An appendix ("annex") contains tables which summarize past decommissioning experiences and future plans in the Member States and there is also an extensive bibliography.

The specific topic of recycling or reuse of components from nuclear facilities is treated in TRS No. 293, "Factors Relevant to the Recycling or Reuse of Components Arising from the Decommissioning and Refurbishment of Nuclear Facilities" [IAEA 1988]. The matter of the availability of relevant radiological criteria is discussed in some detail and reference is made to the current practice of using ad hoc criteria based on existing legislation. Examples are given of the wide: range of permissible levels of contamination which have consequently arisen. Other factors are also discussed but not in as much detail. Over half of the report is given over to an annex whicl deals with monitoring for compliance with the release criteria. 


\section{REGULATIONS IN THE UNITED KINGDOM}

[Gardner 1992] gives a brief overview of the regulation of decommissioning commercial nuclear power stations in practice in the United Kingdom (UK) while [Ross 1990] addresses the regulatory aspects from a slightly different perspective. The latter includes discussion of the safety policy and assessments of the Nuclear Installations Inspectorate (NII), the IAEA decommissioning criteria and the implications of Article 37 of the European Treaty. Though neither article provides examples of specific quantitative guidance with regard to such matters as radiological protection, [Ross 1990] cites the development by the NII of a framework which can be used in safety assessments. This is entitled "Safety Assessment Principles for Nuclear Power Reactors," a document originally produced in 1979 and subsequently amended in 1988. [Ross 1990] further points out that the NII "does not issue standards or codes of practice for nuclear plants. Rather it expects each licensee to develop his own safety design criteria and requirements. These criteria are not formally approved or promulgated as standards or codes, though they may very well make reference to national and international criteria."

Recently, the NII issued "Safety Assessment Principles for Nuclear Plants," a revised version of the earlier documents [NII 1992]. This covers every aspect of a nuclear plant, up to and including decommissioning. Numerical principles are given regarding dose limits and objectives for both the plant workers and the general public, complete with explanatory notes on how the limits had been derived. The document also recommends the performance of probabilistic safety analyses and provides guidance regarding predicted accident frequencies and associated maximum effective doses to offsite persons.

[Neale 1992] provides a useful insight of the way in which directives issued by the European Economic Community (EEC) are transformed into UK legislation. Directives are arrived at following extensive discussion and debate, have to be approved at a meeting of the Council of Ministers and, ultimately, passed by the European Parliament. To quote Neale, "a directive is a legal device used by the EEC to establish policy. The Directive has to be implemented by the individual member states. Usually this involves domestic legislation although some measures may be dealt with by administrative arrangements. The European Commission checks that the Directive has been properly implemented." [Neale 1992] discusses the safety and health requirements as they have emanated from the Directives and how they might affect decommissioning projects. The information as presented covers the many aspects involved in health and safety concerns in general and emphasizes the importance of risk assessments in the overall process. However, it does not contain any mention of the legislation which might specifically address the decontamination and decommissioning of nuclear installations. 


\section{REGULATIONS IN CANADA}

The Canadian policy on the decommissioning of nuclear facilities is described in a Regulatory Policy Statement issued by the Atomic Energy Control Board (AECB) [AECB 1988]. The document itself represents a formal statement of the regulatory process and requirements applicable to the decommissioning of those facilities licensed and regulated by the AECB and is fairly general in nature. The AECB requires that a conceptual decommissioning plan be prepared while a new facility is in the initial design stage or, if a facility is already in operation, that such a plan be developed and submitted to the AECB. The plan should contain, among other items: estimates of the radiation levels and the quantity and types of radioactive substances present in the facility when operation is terminated; a description of the anticipated inventory of radioactive and toxic wastes arising from the decommissioning; a description of the measures taken to limit radiological and other hazards in the event of an accident; and an estimate of the residual radiation levels and the quantities and types of residual hazardous substances. The policy statement does not, however, go into specifics such as defining what are regarded as acceptable residual radiation levels. These are to be found in the individual Atomic Energy Control Regulations.

Paré [Paré 1992] presents the AECL's decommissioning philosophy, explains its. foundations, describes its application to various facilities and summarizes the experience gained to date. In addition to other aspects, he emphasizes that the onus is placed on the owner of a facility to demonstrate the technical feasibility and the financial capability of decommissioning that facility. Gupta [Gupta 1992] points out that the Canadian philosophy derives from the lack of permanent disposal facilities in Canada for commercial radioactive waste.

More detail on decommissioning regulations can be found in [Whitehead 1986]. The author summarizes the history of regulatory development surrounding the decommissioning of uranium mines and mills in Canada and provides a listing of the major relevant documents involved. He follows this with descriptions of the experiences at three mines in closing down their operations and, in an appendix, a summary of the conditions and requirements contained in the AECB approvals for decommissioning at all three mines. The report also contains two comprehensive tables. The first of these summarizes recent AECB regulatory initiatives of relevance to the decommissioning of uranium mines. Table 2 lists the various decommissioning/reclamation activities involved and the associated requirements and criteria. 


\section{REGULATIONS IN GERMANY}

Weil, Görtz and Thierfeldt, [Weil 1992], provide a description of the experiences gained in decommissioning of nuclear installations in Germany. According to the authors, licensing procedures for decommissioning can be conducted on the basis of existing regulations but few of these are specific to decommissioning, per se. Thus regulations designed for the operational phase have to be applied. The authors cite the application of several sections of the Atomic Energy Act (AEA) and the Ordinance on Radiological Protection (ORP) but provide few quantitative examples of what these regulations imply. They do, however, provide some data showing the collective dose received by decommissioning workers from different decommissioning projects and conclude that decommissioning doses are normally less than the typical average collective dose received per annum during light water reactor operation.

[Brennecke 1992] repeats some of the information contained in [Weil 1992], including listing the safety goals established relative to the licensing of decommissioning activities. These have their basis in various sections of the AEA and the ORP but more specific rules are needed for several areas relative to decommissioning projects. The authors also discuss the basic procedures and methods used in D\&D operations, the radiation protection measures that must be taken, the recycling of scrap and aspects of decommissioning wastes. A tabulation is provided of the fifteen nuclear power plants currently shut down and to be (or being). decommissioned.

[Hohenhinnebusch 1992] provides a list of 27 decommissioning projects, encompassing the 15 power plants identified in [Brennecke 1992] and numerous processing facilities. The paper confirms that decommissioning is based on the AEA (particularly, Article 7.3) together with the ORP and the Atomic Procedural Provisions and that no specific rules exist pertaining to decommissioning. Article 7.3 of the AEA is invoked as soon as a nuclear facility is shutdown and "irreversible modifications of the system are planned, as a result of which a new start-up can be excluded." Compliance with the regulations is monitored by experts appointed by the ministry in charge (e.g., the Technical Control Board and the State Institute for Environmental Protection). The authors state that "the permit is granted above all on the basis of the safety report, the very detailed supplementary documents, extensive plans, the dismantling manual, all radiation protection and working instructions, and the safeguards report."

The technical aspects of decommissioning three power reactors are discussed in [Miller 1987]. However, the paper also indicates some of the requirements that had to be met. These include the radioactivity levels permitted in metals to be reused or recycled and the release limit for surface contamination. 


\section{REGULATIONS IN OTHER COUNTRIES}

Little information on the regulatory aspects of decommissioning nuclear installations in other countries has been located at the present time.

Hubert et al. [Hubert 1983] present a review of the problems facing decommissioning in many countries, including France and Sweden, during the early nineteen eighties. The aspects which they treat in most detail are administrative procedures, the financing of decommissioning, the areas of responsibility during and after the operation, and the associated role of insurance.

A discussion of the regulatory aspects concerning decommissioning of nuclear installations in France is given in [Habib 1984]. Habib indicates that, at that time, the French did not have in place any special rules or regulations concerning D\&D and goes on to discuss the application of the general regulations to this particular case. He lists the types of facilities which are defined as "nuclear" and describes the radioactivity limits in force at these installations. Further discussion addresses how the regulations are interpreted in practice and the fiscal aspects of D\&D.

Some information on regulations can be also gleaned from technical papers which describe decommissioning activities at individual facilities. For example, [Roudil 1992] describes D\&D of a prototype vitrification facility at Marcoule. One of the requirements imposed on the operation involved compliance with the waste package specifications issued by French radioactive waste management agency (ANDRA). The paper notes what these are with regard to maximum permissible activity, maximum contact radiation level and maximum one-meter irradiation level.

Wilhelmsson and Larson [Wilhelmsson 1980] describe the situation in Sweden in 1980, at which point in time a referendum was about to be held to determine the future of nuclear power in the country. The authors describe briefly the two laws which govern nuclear energy work in Sweden and indicate that they are not well suited to dealing with decommissioning of nuclear facilities. Thus, irrespective of the outcome of the referendum, new legislation was needed in this area. Legislative activity had already been initiated and would continue.

The decommissioning of nuclear facilities has only recently been initiated in Japan but a comprehensive program to develop the technology and regulations which will be needed is already underway [Komatsu 1993]. According to Komatsu, the policies are determined by the Japan Atomic Energy Commission (JAEC) and implemented by the Science and Technology Agency and the Ministry of International Trade and Industry. The JAEC's long-term program with regard to decommissioning of power plants states that, "in principle, a reactor should be dismantled after termination of its operation and the site should be efficiently re-used for the next generation of nuclear power stations." A non-profit organization, the Research Association for Nuclear Facility Decommissioning (RANDEC), is apparently working on "related legislation and regulations such as licensing procedures for reactor decommissioning, 
certification of site-release criteria and waste management issues." A key point in the Japanese program is that nuclear power plants should be decommissioned to "Stage 3" (sometimes called the "green field" level) [Hoshi 1992; Yokota 1992]. The Japanese are currently in the process of dismantling the Japan Power Demonstration Reactor and analyzing the data obtained during the various activities. The Japan Nuclear Safety Commission published a report entitled "Philosophy of Safety Assurance during Reactor Dismantlement" early in the project (1985) but little information is available of the contents of this report. 


\section{REFERENCES}

[AECB 1988]

[ANSI 1981]

[ASTM 1989]

[ASTM 1988]

[ASTM 1987a]

[ASTM 1987b]

[ASTM 1985]

[Berger 1992]

[Bertini 1986]

Atomic Energy Control Board (Canada), Regulatory Document R-90, Policy on the Decommissioning of Nuclear Facilities, INIS-MF-1292 August 1988.

ANSI/ANS-15.10-1981, American National Standard for Decommissioning of Research Reactors, American Nuclear Society, La Grange Park; IL, September 1981.

ASTM Standard E 1281-89, Standard Guide for Nuclear Facility Decommissioning Plans, American Society for Testing and Materials, Philadelphia, PA, May 1989.

ASTM Standard E 1278-88, Standard Guide for Radioactive Pathway Methodology for Release of Sites Following Decommissioning, American Society for Testing and Materials, Philadelphia, PA, February 1988.

ASTM Standard E 1167-87, Standard Guide for Radiation Protection Program for Decommissioning Operations, American Society for Testing and Materials, Philadelphia, PA, September 1987.

ASTM Standard E 1168-87, Standard Guide for Radiological Protection Training for Nuclear Facility Workers, American Society for Testing and Materials, Philadelphia, PA, September 1987.

ASTM Standard E 1034-85, Standard Specification for Nuclear Facility Transient Worker Records, American Society for Testing and Materials, Philadelphia, PA, March 1985.

J.D. Berger, Manual for Conducting Radiological Surveys in Support of License Termination, NUREG/CR-5849, ORAU-92/C57, June 1992.

A. Bertini, H. Lawton, O. Ilari and S. Menon, The OECD/NEA Cooperative Program Concerning Nuclear Installation Decommissioning Projects, Spectrum '86 Proc. Int. Top. Mtg. Waste Management and Decontamination and Decommissioning, Niagara Falls, 
NY, September 14-18, 1986, American Nuclear Society, Inc., La Grange Park, IL, CONF-860905, Vol. 2, pp. 1859-1869.

[Brennecke 1992]

[Cameron 1992]

[Cantor 1986]

[Conti 1980]

[Crofford 1980]

[De 1991]

[DOE 1988]

[DOE 1992]

[EG\&G 1978]
P. Brennecke, H.P. Berg and L. Weil, The German Approach to Decommissioning of Nuclear Installations, in Decommissioning and Demolition 1992 (Proc. Third Intl. Conf. Decommissioning Offshore, Onshore Demolition and Nuclear Works, Manchester, U.K., March 25-26, 1992), I.L. Whyte, ed., Thomas Telford Ltd., London, 1992, pp. 42-49.

F.X. Cameron, Towards a US Decommissioning Rule, Nucl. Eng. International 37:16-17 (August 1992).

R. Cantor, Nuclear Reactor Decommissioning: An Analysis of the Regulatory Environments, ORNL/TM9638, August 1986.

E.F. Conti, Residual Activity Criteria for Decommissioning, in Decommissioning Requirements in the Design of Nuclear Facilities, Nuclear Energy Agency, Organisation for Economic Co-operation and Development, Paris 1980, pp. 91-102.

W.N. Crofford, Decommissioning Standards, in Decontamination and Decommissioning of Nuclear Facilities (M.M. Osterhout, ed.), Plenum Press, New York, 1980, pp. 17-23.

P.L. De, New Emphasis of IAEA's Program on Decommissioning, Waste Management '91 (R.G. Post, ed.), Vol. 1, pp. 131-136 (1991).

United States Department of Energy, DOE Order 5820.2A, Radioactive Waste Management, September 26, 1988.

United States Department of Energy, DOE N 5480.6, Radiological Control Manual, June 1992.

EG\&G Idaho Inc., Radioactive Contamination Control Program, Safety Manual Section 5040, January 1978. 
[Faust 1980]

[Feraday 1985]

[GAO 1989]

[Gardner 1992]

[Gupta 1992]

[Habib 1984]

[Hine 1981]

[Hohenhinnebusch 1992]

[Hoshi 1992]
R.A. Faust, C.S. Fore and N.P. Knox, Nuclear Facility Decommissioning and Site Remedial Actions - A Selected Bibliography Vol.1, ORNL/EIS-154/V1, September 1980.

M.A. Feraday, Regulations, Standards and Criteria in Decommissioning, Proc. Intl. Nuclear Reactor Decommissioning Planning Conference, Bethesda, MD, July 16,1985 , CONF-850720, pp. 43-54.

United States Gereral Accounting Office, NRC's Decommissioning Procedures and Criteria Need to be Strengthened, GAO/RCED-89-119, May 1989.

P.H. Gardner and A.C. Rae, The Regulation of Decommissioning Nuclear Power Reactors in Practice, Nuclear DECOM '92: Decommissioning of Radioactive Facilities International Conference, February 17, 1992, Mechanical Engineering Publications Ltd., London, U.K., pp. 67-71.

B. Gupta, Progress of Decommissioning Projects in Canada, Nuclear DECOM '92: Decommissioning of Radioactive Facilities International Conference, February 17, 1992, Mechanical Engineering Publications Ltd., London, U.K., pp. 189-194.

F. Habib, Les Aspects Réglementaires du Déclassement des Installations Nucléaires du Base, FRNC-CONF-217, December 1984.

R.E. Hine, Decontamination and Decommissioning of the SPERT-II and SPERT-III Reactors at the Idaho National Engineering Laboratory, EG\&G-2074, February 1981.

W. Hohenhinnebusch and G. Engelhardt, Decommissioning Projects and Decommissioning Experiences Gained in Germany, Proc. 8th Pacific Basin Nuclear Conference, April 12-16, 1992, Trans. ANS 65 (Supplement 2): 6.B-1 - 6.B-7 (1992).

T. Hoshi, S. Yanagihara, M. Tachibana and T. Momma, Decommissioning Experience of the Japan Power Demonstration Reactor, Nuclear DECOM '92: Decommissioning of Radioactive Facilities International 
[Hubert 1983]

[IAEA 1980]

[IAEA 1982]

[IAEA 1986a]

[IAEA 1987a]

[IAEA 1990]

[IAEA 1988]

[IAEA 1987b]

[IAEA 1986b]
Conference, February 17, 1992, Mechanical Engineering Publications Ltd., London, U.K., pp. 157-162.

E.H. Hubert, G. Andersson, J. Deprimoz, J.C. Mayoux, F. Nocera, M. Richard and C. Sartorelli, Decommissioning of Nuclear Plants: Regulations - Financing-ResponsibilityInsurance, Sixth Session of Nuclear Inter Jura '83, San Francisco, September 11, 1983, INIS-MF-9563.

International Atomic Energy Agency, Safety Series No. 52, Factors Relevant to the Decommissioning of LandBased Nuclear Reactor Plants, August 1980.

International Atomic Energy Agency, Safety Series No. 9, Basic Safety Standards for Radiation Protection - 1982 Edition, August 1982.

International Atomic Energy Agency, Safety Series No. 74, Safety in Decommissioning of Research Reactor, February 1986.

International Atomic Energy Agency, Safety Series No. 85, Safe Management of Wastes from the Mining and Milling of Uranium and Thorium Ores, June 1987.

International Atomic Energy Agency, Safety Series No. 105, The Regulatory Process for the Decommissioning of Nuclear Facilities, July 1990.

International Atomic Energy Agency, Technical Report Series No. 293, Factors Relevant to the Recycling or Reuse of Components Arising from the Decommissioning and Refurbishment of Nuclear Facilities, December 1988.

International Atomic Energy Agency, Technical Report Series No. 278, Methods for Reducing Occupational Exposures during the Decommissioning of Nuclear Facilities, October 1987.

International Atomic Energy Agency, Technical Report Series No. 267, Methodology and Technology of Decommissioning Nuclear Facilities, September 1986. 
[IAEA 1983]

[ICRP 1977]

[Jones 1993]

[Kennedy 1992]

[Kocher 1985]

[Komatsu 1993]

[Konzek 1978]

[Kovach 1992]

[Lichtman 1985]

[Miller 1987]
International Atomic Energy Agency, Technical Report Series No. 230, Decomnissioning of Nuclear Facilities: Decontamination, Disassembly and Waste Management, December 1983.

International Commission on Radiological Protection, Recommendations of the ICRP, ICRP Publication 26, Pergamon Press, Oxford, 1977.

J.M. Jones, Co-operating to Develop Decommissioning Techniques, Nucl. Eng. International 38:28-29 (1993).

W.E. Kennedy, Jr., and D.L. Strenge, Residual Radioactive Contamination from Decommissioning Technical Basis for Translating Contamination Levels to Annual Total Effective Dose Equivalent, NUREG/CR5512, PNL-7994, Vol. 1, October 1992.

D.C. Kocher, National and International Considerations of a De Minimis Dose, in Health Physics Considerations in Decontamination and Decommissioning, CONF-860203, December 1985, pp. 9-18.

J. Komatsu, Planning for Decommissioning Power Plants in Japan, Nucl. Eng. International 38:22,24 (1993).

G.J. Konzek and C.R. Sample, Decommissioning of Nuclear Facilities - An Annotated Bibliography, NUREG/CR-0131, October 1978.

P.J. Kovach, Proposed Rulemaking: Timeliness in Decommissioning Nuclear Materials Facilities, Trans. ANS 66:72-73 (1992).

S. Lichtman and M. Ronca-Battista, Development of Residual Radioactivity Criteria, in Health Physics Considerations in Decontamination and Decommissioning, CONF-860203, December 1985, pp. 1-7.

R.L. Miller, Power Reactor Decommissioning Projects in the Federal Republic of Germany, Proc. Fifteenth Water Reactor Safety Information Meeting, Volume 6 - 
[Neale 1992]

[NII 1992]

[NRC 1974]

[NRC 1978]

[NRC 1988]

[NRC 1989]

[Paré 1992]

[Ronca-Battista 1985]
Decontamination and Decommissioning, NUREG/CP-0091 Vol. 6, pp. 61-65 (1987).

B.S. Neale, Safety and Health Requirements Following European Community Directives, in Decommissioning and Demolition 1992 (Proc. Third Intl. Conf. Decommissioning Offshore, Onshore Demolition and Nuclear Works), I.L. Whyte, ed., Thomas Telford Ltd., London, 1992, pp. 1-8.

H.M. Nuclear Installations Inspectorate, Safety Assessment Principles for Nuclear Plants, HMSO, London, U.K., October 1992.

United States Atomic Energy Commission, Regulatory Guide 1.86, Termination of Operating Licenses for Nuclear Reactors, June 1974.

United States Nuclear Regulatory Commission, Plan for Reevaluation of NRC Policy on Decommissioning of Nuclear Facilities, NUREG-0436, Revision 1, December 1978 (Supplements 1 and 2 issued in Aur.ust 1980 and March 1981, respectively).

United States Nuclear Regulatory Commission, Final Generic Impact Statement on Decommissioning of Nuclear Facilities, NUREG-0586F, May 1988.

United States Nuclear Regulatory Commission, Draft Regulatory Guide - Standard Format and Content for Decommissioning Plans for Nuclear Reactors, September 1989.

F.E. Paré, Canadian Decommissioning Experience from Policy to Project, Proc. 8th Pacific Basin Nuclear Conference, April 12-16, 1992, Trans. ANS 65 (Supplement 2): 6.D-1 - 6.D-6 (1992).

M. Ronca-Battista and J.C. Hardeman, Jr., Inventory of Sites Used to Develop Residual Radioactivity Criteria, in Health Physics Considerations in Decontamination and Decommissioning, CONF-860203, December 1985, pp. 539-542. 
[Ross 1990]

W.M. Ross, Regulatory Aspects of Nuclear Reactor Decommissioning, Decommissioning and Demolition 1990 (Proc. Intl. Conf. on Decommissioning Offshore, Onshore Demolition and Nuclear Works, Manchester, U.K., April 24-26, 1990), I.L. Whyte, ed., Thomas Telford Ltd., London, pp. 164-170.

[Roudil 1992]

S. Roudil, G. Scelo, C. Deschaud and A. Jouan, Decontamination and Dismantling of the PIVER Prototype Vitrification Facility at Marcoule (France), Waste Management '92 (R.G. Post, ed.), Vol. 1, pp. 729-733 (1992).

[Schilling 1979]

A.H. Schilling, H.E. Lippek, P.D. Tegeler and J.D. Easterling, Decommissioning Commercial Nuclear Facilities: A Review and Analysis of Current Regulations, NUREG/CR-0671, August 1979.

[Steffes 1988]

D.R. Steffes, Status of Industry Standards for Decommissioning of Nuclear Facilities, Spectrum '88 Proc. Int. Top. Mtg. Nuclear and Hazardous Waste Management, Pasco, WA, September 11-15, 1988, American Nuclear Society, Inc., La Grange Park, IL, pp. 437-440.

[Stello 1980]

[Voillequé 1985]

V. Stello, Jr., NRC's View of Decontamination and Decommissioning, in Decontamination and Decommissioning of Nuclear Facilities (M.M. Osterhout, ed.), Plenum Press, New York, 1980, pp. 9-12.

P.G. Voillequé, Dose Guidelines for Decontamination and Decommissioning Projects, in Health Physics Considerations in Decontamination and Decommissioning, CONF-860203, December 1985, pp. 27-36.

[Weil 1992]

L. Weil, R. Görtz and S. Thierfeldt, Decommissioning in the Federal Republic of Germany - Experiences, Regulations and Developments, Nuclear DECOM '92: Decommissioning of Radioactive Facilities International Conference, February 17, 1992, Mechanical Engineering Publications Ltd., London, U.K., pp. 229-234. 
[Whitehead 1986]

[Wilhelmsson 1980]

[Wittenbrock 1982]

[Wynveen 1985]

[Yokota 1992]
W. Whitehead, Decommissioning of Uranium Mines and Mills - Canadian Regulatory Approach and Experience, INFO-0219, September 1986.

H. Wilhelmsson and A. Larsson, Some Regulatory Aspects on the Decommissioning of Nuclear Power Plants, in Decommissioning Requirements in the Design of Nuclear Facilities, Nuclear Energy Agency, Organisation for Economic Co-operation and Development, Paris 1980, pp. 83-87.

N.G. Wittenbrock, Technology, Safety and Costs of Decommissioning Nuclear Reactors at Multiple-Reactor Stations, NUREG/CR-1755, January 1982.

R.A. Wynveen, H.J. Moe, M.J. Robinet and V.R. Veluri, Residual Surface Contamination Limits: Problems in Interpretation and Implementation, in Health Physics Considerations in Decontamination and Decommissioning, CONF-860203, December 1985, pp. 39-50.

M. Yokota, S. Yanagihara, I. Miki and T. Hoshi, The Japan Power Demonstration Reactor Decommissioning Program - Experience of Nuclear Power Reactor Dismantling, Proc. 8th Pacific Basin Nuclear Conference, April 12-16, 1992, Trans. ANS 65 (Supplement 2): 6.C-1 6.D-8 (1992). 
11
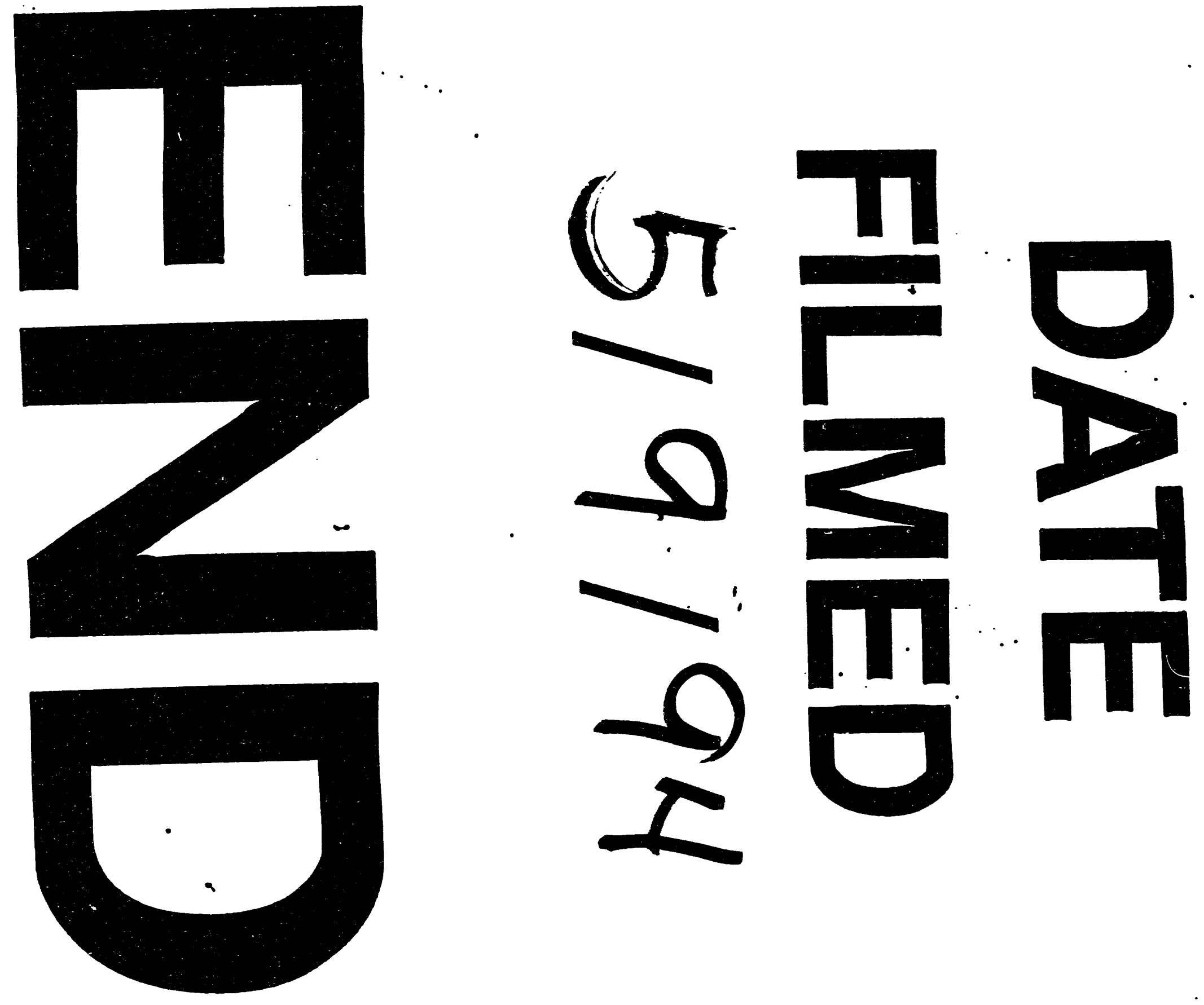


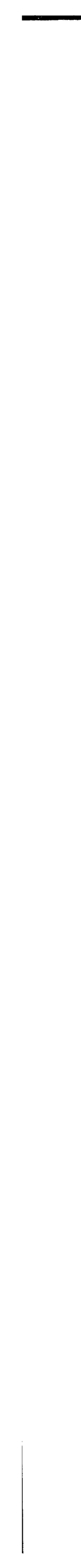

